Vítor Monteiro, Andrés A. Nogueiras Meléndez, João L. Afonso

"Novel Single-Phase Five-Level VIENNA-Type Rectifier with Model Predictive Current Control"

IEEE IECON Industrial Electronics Conference, pp. 6413-6418, Beijing China, Oct. 2017.

DOI: 10.1109/IECON.2017.8217117

ISBN: 978-1-5386-1127-2

This material is posted here with permission of the IEEE. Such permission of the IEEE does not in any way imply IEEE endorsement of any of Group of Energy and Power Electronics, University of Minho, products or services. Internal or personal use of this material is permitted. However, permission to reprint/republish this material for advertising or promotional purposes or for creating new collective works for resale or redistribution must be obtained from the IEEE by writing to pubs-permissions@ieee.org. By choosing to view this document, you agree to all provisions of the copyright laws protecting it. 


\title{
Novel Single-Phase Five-Level VIENNA-Type Rectifier with Model Predictive Current Control
}

\author{
Vítor Monteiro $^{1}$, Andrés A. Nogueiras Meléndez ${ }^{2}$, João L. Afonso ${ }^{1}$ \\ ${ }^{1}$ ALGORITMI Research Centre - University of Minho, Guimarães - Portugal \\ ${ }^{2}$ Departamento de Tecnología Electrónica - University of Vigo, Vigo - Spain \\ ${ }^{1}\left\{\right.$ vitor.monteiro | joao.1.afonso\}@algoritmi.uminho.pt ${ }^{2}$ aaugusto@uvigo.es
}

\begin{abstract}
A novel single-phase five-level active rectifier based on the VIENNA-type rectifier with model predictive current control is presented. The proposed topology operates in unidirectional mode, imposing a sinusoidal grid-side current with unitary power factor. A unidirectional electric vehicle battery charger is the target application in which the proposed rectifier is used; however, it can also be used as an active rectifier for other purposes aiming to improve the efficiency of ac-to-dc rectification. The model predictive current control is used to select the active rectifier state during each sampling period, trying to minimize the grid current error and obtain low total harmonic distortion. The suitability and performance of the proposed topology of active rectifier, as well as the principle of operation and the digital control algorithm, are evaluated through simulation and experimental results.
\end{abstract}

Keywords-Active Rectifier; Five-Level; Model Predictive Current Control, Power Quality.

\section{INTRODUCTION}

Active rectifiers have gained notoriety in the last decades as alternative to diode and multi-pulse rectifiers, mainly due to the controlled grid-side current and output-side voltage [1][2]. Therefore, several topologies with different levels of complexity have been proposed for single-phase [3][4] and three-phase [5] systems. The core of active rectifiers, exploring the different characteristics of each one, is presented in [6] and [7]. Besides the power-factor-correction (PFC) converters [8], a particular classification of active rectifiers is the multi-level attribute, i.e., the distinct number of voltage levels that the active rectifier can produce during the positive and negative half-cycles. Multi-level active rectifiers are used to reduce the harmonic distortion of the grid-side current and to reduce the coupling passive filters. Typically, the most commonplace multi-level active rectifiers used in industrial applications are the neutral-point-clamped, the cascade topologies, and the VIENNA-type rectifiers [9][10].

VIENNA rectifier was initially proposed for three-phase systems in order to improve the efficiency and the power quality in the grid-side, using just three switching devices [11]. Along the last years, some topologies based on VIENNA rectifier were proposed for different applications. A novel single-stage topology based on the VIENNA rectifier used in three-phase systems and with output isolated in high-frequency is proposed in [12], but it cannot be rearranged for single-phase systems. The operation of a three-phase VIENNA rectifier as an active shunt power filter for power quality improvement is proposed in [13]. Although such topology operates as a three-phase converter, a single-phase converter can be derived, but operating as a double-boost, i.e., with the double of the output voltage. A five-level converter based on the VIENNA rectifier is proposed in [14] as an active rectifier, however, such topology is applicable only for three-phase systems and requires an extra hardware structure for the dc voltage balancing. A new single-phase five-level converter based on the VIENNA rectifier is proposed in [15] for high-current applications, however, to obtain the same results, such converter requires more and complex hardware than the topology proposed in this paper. A single-phase converter based on the VIENNA rectifier with a single-switch for EV battery chargers applications is proposed in [16], however, it is a three-level topology and operates as a double-boost with the double of the output voltage compared with the proposed topology. A five-level converter, derived from a VIENNA rectifier topology, used for active rectifiers applications is proposed in [17], however, it operates as double-boost and requires more diodes and switching devices.

The most traditional active rectifier is the PFC that comprises a diode bridge rectifier with a dc-dc boost converter operating in continuous mode. This active rectifier, considering the different positions of the active and passive devices, is presented in Fig. 1(a-c). This active rectifier is classified as two-level, since the voltage $v_{a b}$ can have two distinct values. Comparing the traditional single-phase VIENNA rectifier (cf. Fig. 1(d)) with the traditional PFC (cf. Fig. 1(a)), it requires one more diode and a split dc-link, but it is able to produce three distinct voltage levels. However, the double-boost characteristic of the output voltage can signify a relevant drawback. A five-level boost-type active rectifier (FLAR) with a split dc-link is presented in Fig. 1(e) [2]. Comparing with the VIENNA rectifier, it can produce more voltage levels with just more two switching devices and less one diode, and without the double-boost characteristic of the dc-link voltage. Combining both active rectifiers, the proposed topology of a five-level active rectifier is shown in Fig. 1(f). Such topology aggregates the main advantages of both VIENNA and FLAR, i.e., it is a five-level topology without a double-boost characteristic and with a reduced number of switching devices. The proposed topology has a split dc-link, but the middle point is connected to the neutral wire of the power grid through a bidirectional cell, which is composed by two IGBTs in a common-emitter configuration. Besides the passive filter $(L)$ to couple with the power grid, it is composed by a diode bridge rectifier (diodes $d 1$ to $d 4$ ), by a bidirectional cell (IGBTs $g 2$ and $g 3$ ), by the main switching IGBT and by the diode $d 5$. 


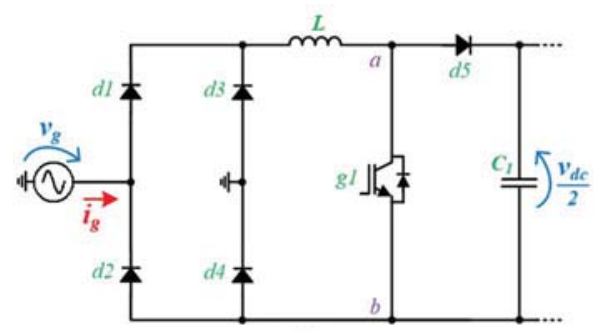

(a)

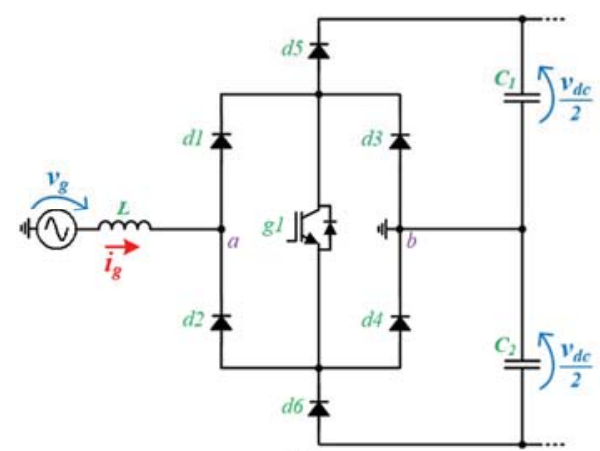

(d)

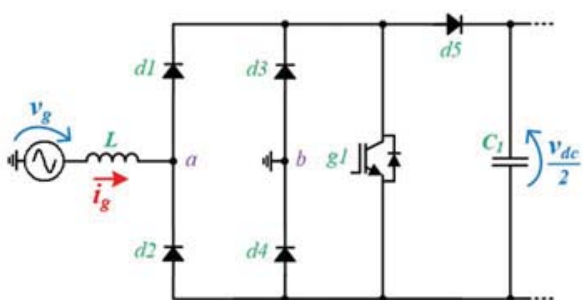

(b)

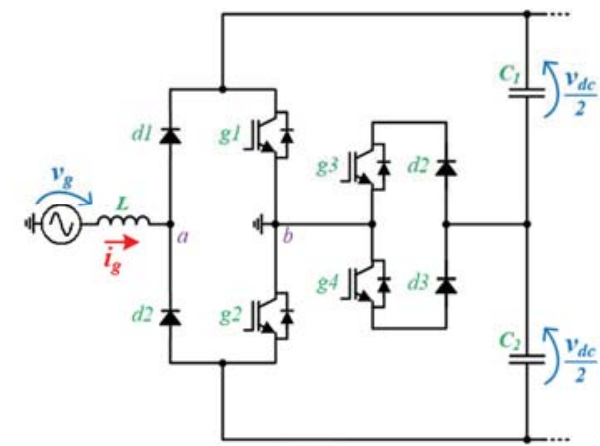

(e)

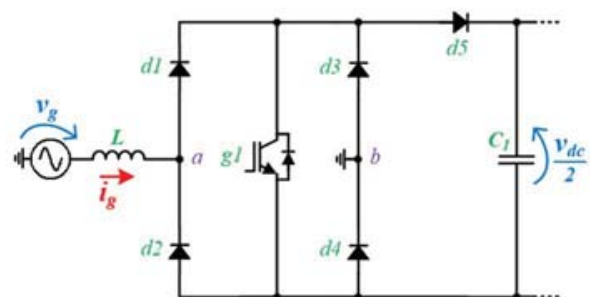

(c)

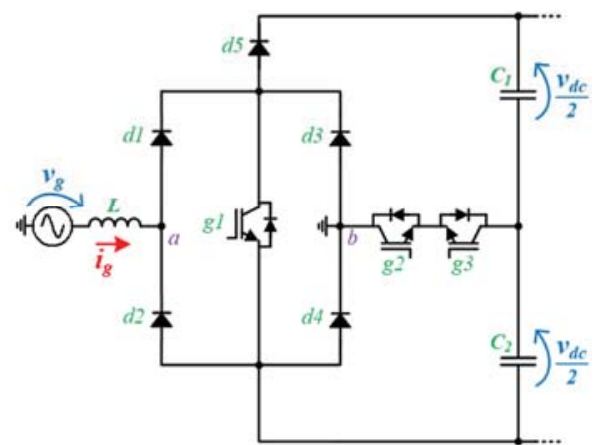

(f)

Fig. 1. Evolution from the traditional PFC (a), and its different configurations (b)-(c), to the VIENNA rectifier, to the FLAR topology (e), and to the proposed five-level active rectifier.

The model predicitve current control of the proposed active rectifier is presented in section II, and a comprehensive and detailed analysis, including the main simulation results, is presented in section III. An experimental validation is presented in section IV, and the main conclusions are presented in section $\mathrm{V}$.

\section{Model Predictive CurRent CONTROL}

Model predictive current control has been applied with success as a method to control power converters [18][19], including current-source [20] or voltage-source converters [21]. It is important to note that the proposed active rectifier can be controlled applying other current control strategies (e.g., sinusoidal PWM or sliding mode); however, the model predictive control was selected due to its robustness and simplicity of implementation.

During each sampling period established by the digital controller, the state of the active rectifier will define the grid-side current. Thus, a model predictive current control with finite control set (MPC-FCS) is used to define the state of the active rectifier, i.e., to the grid-side current track its reference. The different states allowed by the proposed active rectifier are shown in Fig. 2. During the positive half-cycle (Fig. 2(a-c)), the IGBT $g l$, and the diodes $d_{l}$ and $d_{4}$, are used to obtain the voltage level zero $\left(v_{a b}=0 \mathrm{~V}\right)$, i.e., the inductance stores energy and the current will increase to track the reference. The voltage level $v_{d c} / 2\left(v_{a b}=v_{d c} / 2 \mathrm{~V}\right)$ is obtained with the IGBT $g 3$, the diodes $d 1$ and $d 5$, and the reversible diode of the IGBT $s 2$. The voltage level $v_{d c}\left(v_{a b}=v_{d c} \mathrm{~V}\right)$ is obtained just with the diodes $d 1, d 4$ and $d 5$. During the negative half-cycle (Fig. 2(d-f)), the IGBT $g 1$, and the diodes $d 2$ and $d 3$, are used to obtain the voltage level zero $\left(v_{a b}=0 \mathrm{~V}\right)$. The voltage level $-v_{d c} / 2$ $\left(v_{a b}=-v_{d c} / 2 \mathrm{~V}\right)$ is obtained with the IGBT $g 2$, the diode $d 2$, and the reversible diode of the IGBT $s 3$. The voltage level $-v_{d c}$ $\left(v_{a b}=-v_{d c} \mathrm{~V}\right)$ is obtained just with the diodes $d 2, d 3$, and $d 5$.

\section{A. Power Theory-Grid-side Current Reference}

The main characteristic of an active rectifier is the grid-side sinusoidal current. For this reason, a sinusoidal reference should be established. Since the rms value of the power grid voltage is known, the amplitude of the current reference is determined by the operating power of the active rectifier, which can be calculated as the sum of the power delivered to the dc load with power necessary to regulate the dc-link voltage. Applying the Fryze-Buchholz-Depenbrock (FBD) power theory, the instantaneous value of the current reference $\left(i_{g}{ }^{*}\right)$ is established according to:

$$
i_{g}^{*}(t)=\frac{p_{d c}}{V_{G}{ }^{2}} v_{g}(t)
$$

where, $p_{d c}$ denotes the dc-side power, $V_{G}$ the rms value of the power grid voltage, and $v_{g}$ its instantaneous value. Applying this strategy, the amplitude and phase of the current reference is dynamically determined by the dc-side power and by the power grid voltage, which can be a drawback in the presence of a power grid voltage with high total harmonic distortion (THD). This drawback can be solved using a phase-locked loop to extract the phase and amplitude of the power grid voltage. Therefore, a sinusoidal current reference is obtained even in the presence of a distorted power grid voltage. The discrete implementation of (1) using a PLL [22], results in:

$$
i_{g}{ }^{*}[n]=\frac{\left(v_{d c}[n] * i_{d c}[n]\right)+p_{c}[n]}{V_{P L L_{G}}[n] * V_{P L L_{G}}[n]} v_{p l l_{g}}[n] .
$$

During each sampling period established by the digital control platform, and knowing the instantaneous value of the current reference and the finite distinct states allowed by the active rectifier, a model predictive current control is used to select the state that forces the grid-side current to track its reference, i.e., the state that minimizes the grid-side current error. 


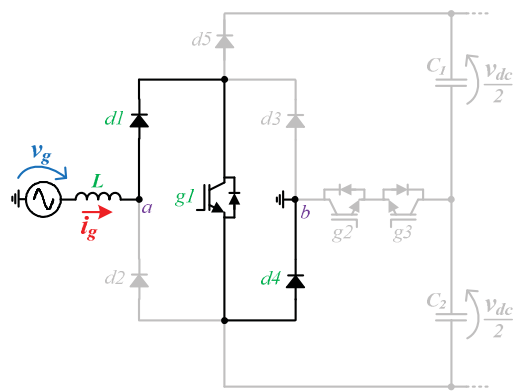

(a)

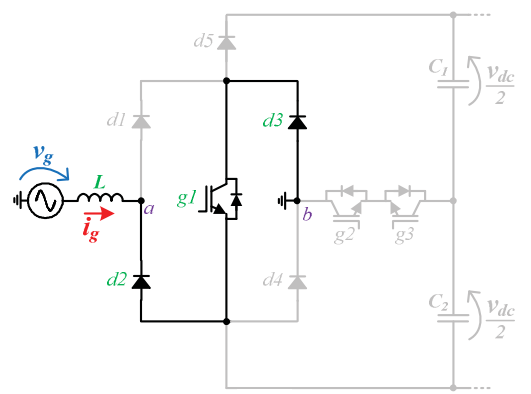

(d)

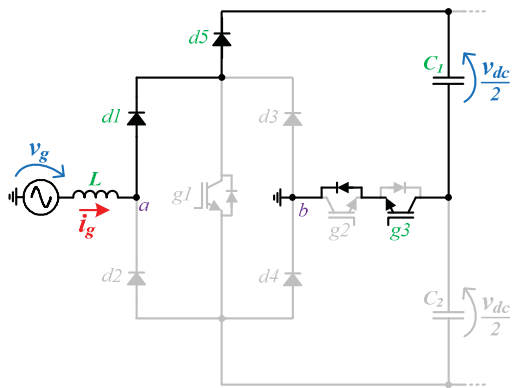

(b)

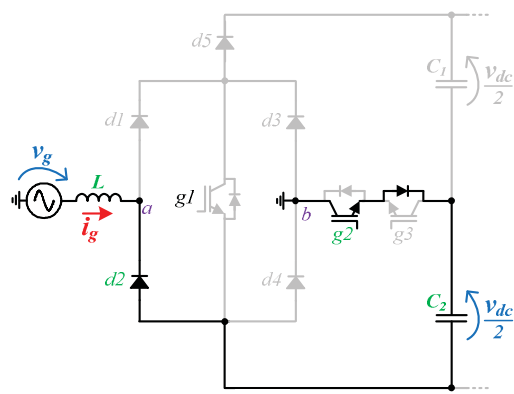

(e)

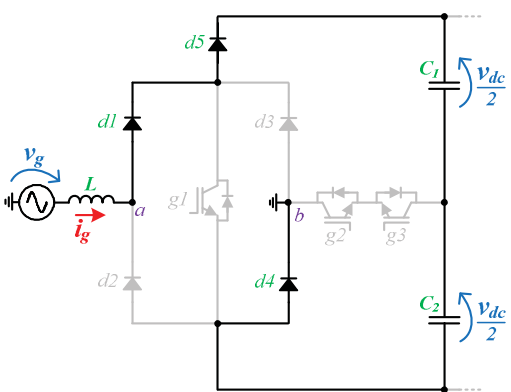

(c)

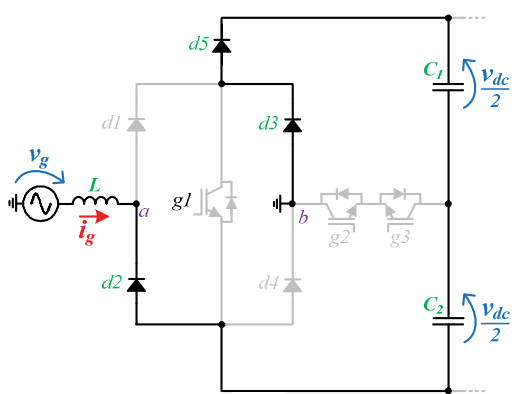

(f)

Fig. 2. Operation stages of the proposed five-level active rectifier: (a)-(c) When $v_{g}>0$; (d)-(f) When $v_{g}<0$.

\section{B. Predictive Model-Predicted Grid-side Current}

Analyzing the voltages and the current represented in Fig. 2(f), and taking into account that the objective is control the grid-side current $\left(i_{g}\right)$, it can be established:

$$
\frac{d i_{g}(t)}{d t}=\frac{v_{g}(t)-v_{a b}(t)}{L}
$$

where, $v_{a b}$ is the voltage produced by the converter during each sampling interval. Applying the forward Euler method to discretize the model, (3) can be rewritten as:

$$
\frac{i_{g}[n+1]-i_{g}[n]}{T}=\frac{v_{g}[n]-v_{a b}[n]}{L} .
$$

Rewritten (4) in terms of the current at $[n+1]$ :

$$
i_{g}[n+1]=\frac{T}{L}\left(v_{g}[n]-v_{a b}[n]\right)+i_{g}[n] .
$$

\section{Predictive Model-Cost Function}

With the grid-side current reference (cf. section II.A) and with the predict grid-side current (cf. section II.B) a cost function to minimize the error between both is used:

$$
g[n+1]=\left\|i_{g}{ }^{*}[n+1]-i_{g}[n+1]\right\|^{2},
$$

where, the current reference at the instant $[n+1]$ can be extrapolated from the previous samplings as [23]:

$$
\begin{gathered}
i_{g}{ }^{*}[n+1]=4 i_{g}{ }^{*}[n]-6 i_{g}{ }^{*}[n-1]+ \\
+4 i_{g}{ }^{*}[n-2]-i_{g}{ }^{*}[n-3] .
\end{gathered}
$$

The cost function is used to define the active rectifier state that forces the grid-side current to follow its reference.

\section{ANALYSIS AND SIMULATION RESULTS}

In this section, the operation of the proposed active rectifier is analyzed in order to show its dynamic performance and the model predictive strategy. The proposed active rectifier was simulated using the PSIM software with a time-step of $1 \mu \mathrm{s}$ and a sampling frequency of $40 \mathrm{kHz}$. For the inductor $(L)$ was selected a value of $5 \mathrm{mH}$ and for the dc-link capacitors $\left(C_{l}\right.$ and $C_{2}$ ) was selected a value of $1.5 \mathrm{mF}$.

The steady-state operation of the proposed active rectifier with the model predictive control is shown in Fig. 3. These results were obtained for an operating power of $3.2 \mathrm{~kW}$. To simulate the proposed active rectifier under real conditions of operation, it is connected to a power grid voltage of $230 \mathrm{~V} \mathrm{rms}$ $(50 \mathrm{~Hz})$ with a THD $\%$ of $3 \%$. As shown, the grid-side current $\left(i_{g}\right)$ is synchronized with the power grid voltage $\left(v_{g}\right)$ to ensure the operation with unitary power factor. Moreover, the grid-side current presents a THD $\%$ of $2.3 \%$, which is an admissible according with the IEEE requirements [24], since it is used a PLL instead of the power grid voltage in the current reference establishment. The dc-link voltage of each capacitor $\left(v_{d c l}\right.$ and $\left.v_{d c 2}\right)$ is controlled according to a voltage reference of $200 \mathrm{~V}$, performing a total dc-link voltage of $400 \mathrm{~V}$. These voltages present a natural oscillation, since it is not possible to obtain a constant power from the power grid using an active rectifier in single-phase installations. As shown, the five distinct voltage levels $\left(v_{a b}\right)$ are clearly defined in both positive and negative half-cycles, illustrating the proper operation of the proposed controller.

The grid-side current and the currents in the different semiconductors of the proposed active rectifier are shown in Fig. 4. As shown, the IGBT $g 1$ is only used to produce the voltage level zero, and the IGBTs $g 2$ and $g 3$ are used during both positive and negative half-cycles. The proposed active rectifier was also simulated in transient mode aiming to verify its dynamic operation, as well as the applied model predictive control. As shown in Fig. 5, the first test was performed considering a step change of $50 \%$ in the output load. As expected, the sudden variation in the load affects the amplitude of the grid-side current, but it remains controlled (following its reference) and in phase with the power grid voltage (i.e., operating with unitary power factor), and also the dc-link 

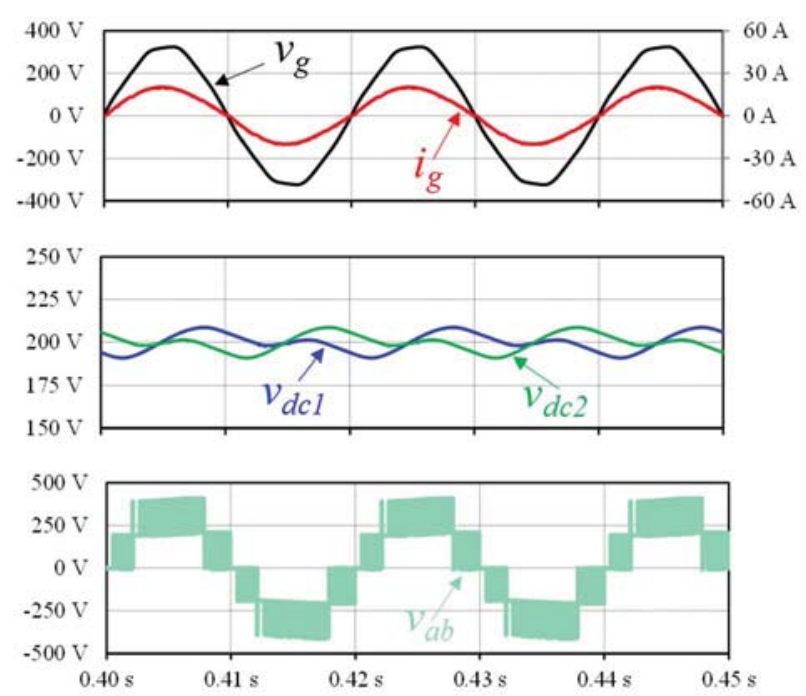

Fig. 3. Simulation results in steady-state: Grid-side voltage $\left(v_{g}\right)$; Grid-side current $\left(i_{g}\right)$; Dc-link voltages $\left(v_{d c}, v_{d c}\right)$; Produced voltage $\left(v_{a b}\right)$.
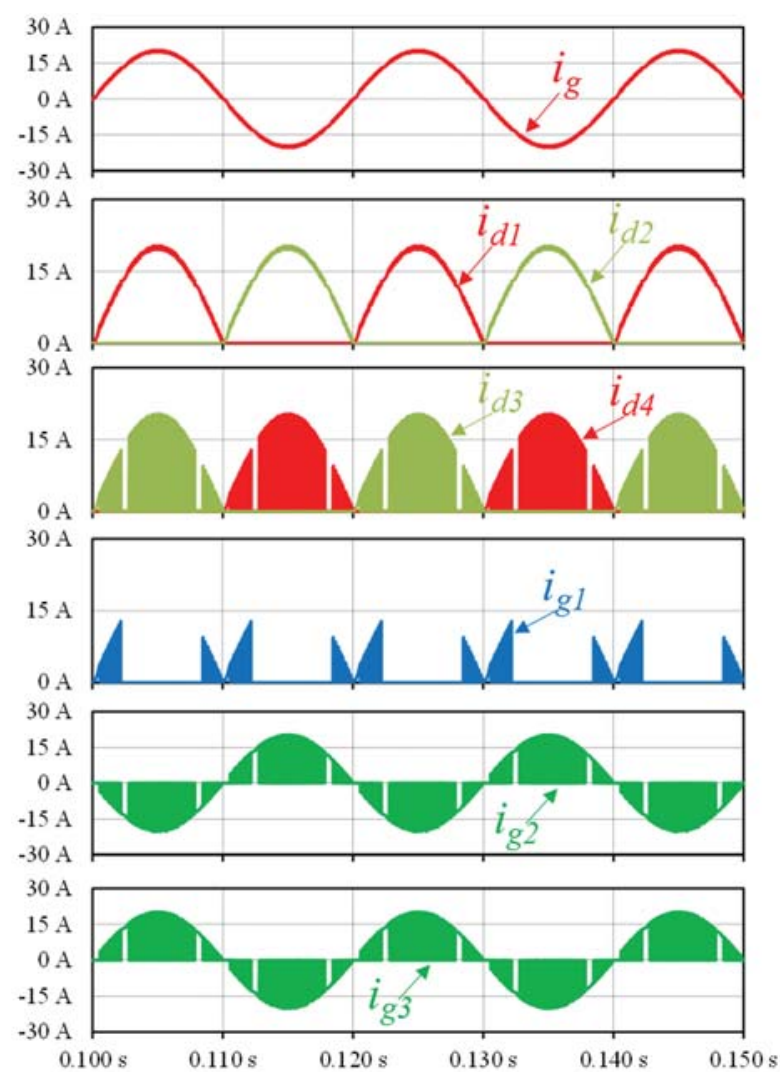

Fig. 4. Simulation results: Grid-side current $\left(i_{g}\right)$; Current in the full-bridge diodes $(d 1, d 2, d 3, d 4)$; Current in the IGBTs $\left(i_{g 1}, i_{g 2}, i_{g 3}\right)$.

voltages remain controlled, as well as the voltage levels of $v_{a b}$. As a second test, shown in Fig. 6, a step-change of $10 \%$ in the power grid voltage was considered. During this step change the grid-side current remains sinusoidal and in phase with the power grid voltage, but with higher amplitude (i.e., the rms value was increased) in order to maintain the same operating power. The mean value of the dc-link voltages are controlled for the reference of $200 \mathrm{~V}$ independently of the variations in the power grid voltage, and the voltage $v_{a b}$ presents the five
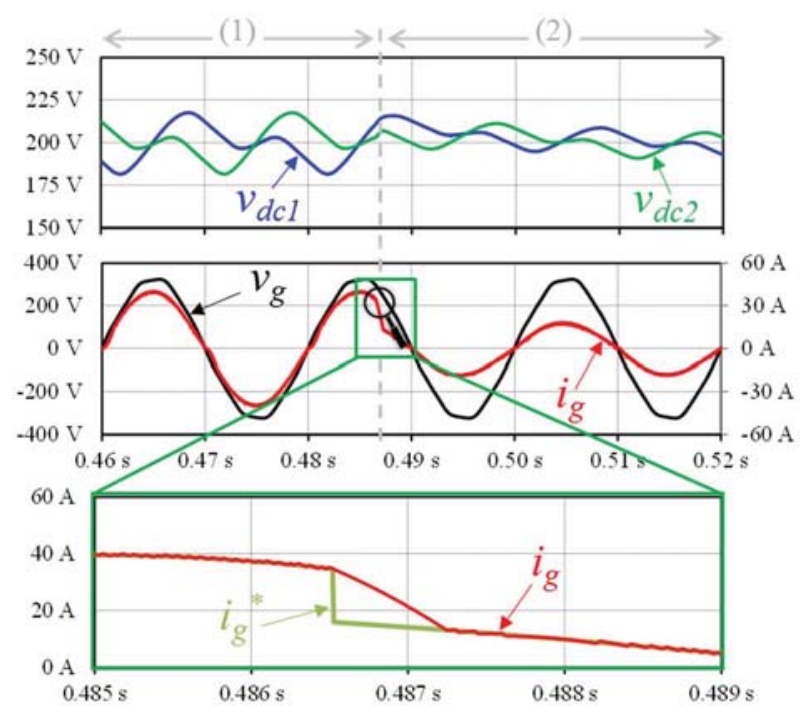

Fig. 5. Simulation results during a step-change in the reference: Dc-link voltages $\left(v_{d c l}, v_{d c 2}\right)$; Grid-side voltage $\left(\mathrm{v}_{\mathrm{g}}\right)$; Grid-side current $\left(i_{\mathrm{g}}\right)$.

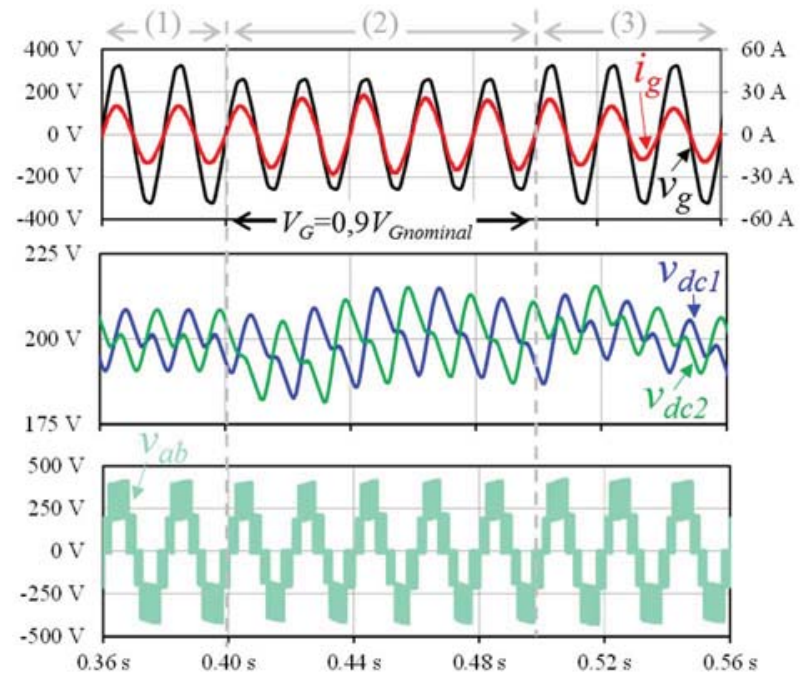

Fig. 6. Simulation results during a step-change in the grid-side voltage: Grid-side voltage $\left(v_{g}\right)$; Grid-side current $\left(i_{g}\right)$; Dc-link voltages $\left(v_{d c l}, v_{d c 2}\right)$; Produced voltage $\left(v_{a b}\right)$.

levels. Therefore, from the load point of view, the converter operates without variation in the power grid voltage.

\section{EXPERIMENTAL VALIDATION}

A laboratorial prototype was built to validate the proposed active rectifier both in terms of power hardware and control strategy. For the diodes was used the model BYC8-600 and for the IGBTs the model FGA25N120ANTD. The digital control algorithm was implemented in the DSP TMS320F28335 with a sampling time of $40 \mu \mathrm{s}$. The prototype was connected to the power grid of $115 \mathrm{~V}$ for a real condition of operation and was used a resistive dc load of $100 \Omega$. The main experimental results during the steady-state of the proposed active rectifier are shown in Fig. 7. Although the power grid voltage presents a clear harmonic distortion, this figure shows that the grid-side current is sinusoidal. The measured THD $\%$ was $2.5 \%$, and the total power factor was 0.99 . In this figure is possible to verify that the dc-link voltage of each capacitor is controlled 


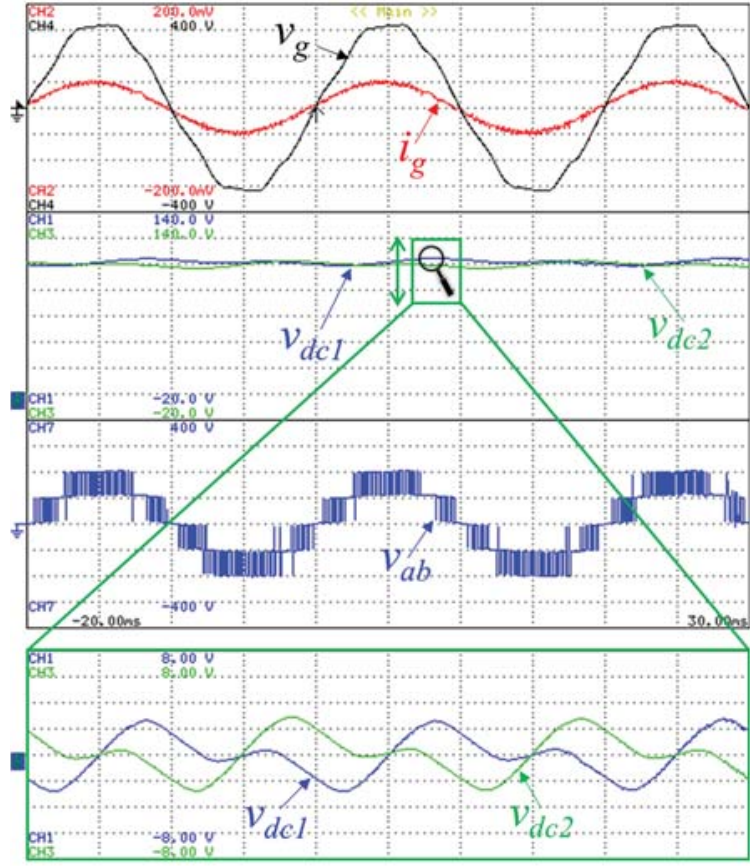

Fig. 7. Experimental results in steady-state: Grid-side voltage $\left(v_{g}\right)$; Grid-side current $\left(i_{g}\right)$; Dc-link voltages $\left(v_{d c 1}, v_{d c}\right)$; Produced voltage $\left(v_{a b}\right)$.

according to a reference of $100 \mathrm{~V}$, performing a total dc-link voltage of $200 \mathrm{~V}$. As shown in detail, the dc-link voltage of each capacitor presents a maximum oscillation of $6 \mathrm{~V}$. Due to the control strategy, each dc-link voltage oscillates with a frequency of $50 \mathrm{~Hz}$. The voltage produced by the proposed active rectifier, i.e., the voltage $v_{a b}$, assumes five distinct levels, validating the proposed control strategy.

The starting operation of the proposed control strategy is shown in Fig. 8. During the time interval (1), all the IGBTs are off, the grid-side current presents the typically waveform of a full-bridge diode rectifier, and the dc-link voltages are imposed by half of the maximum amplitude of the grid-side voltage. When the control strategy is activated, i.e., during the time interval (2), the grid-side current becomes sinusoidal in phase with the power grid voltage, each dc-link voltage increases during $130 \mathrm{~ms}$ without sudden variations until the reference of $100 \mathrm{~V}$, and the voltage $v_{a b}$ assumes the five distinct levels. This figure also shows in a detail of $1 \mathrm{~ms}$, the grid-side current and the voltage $v_{a b}$ when this voltage varies between 0 and $+v_{d c} / 2$. As expected, when the voltage $v_{a b}$ is $0(g 1=1, g 2=0, g 3=0)$, the grid-side current increases (the inductance stores energy), and when the voltage $v_{a b}$ is $+v_{d c} / 2(g 1=0, g 2=0, g 3=1)$, the grid-side current decreases (the inductance delivers energy).

The gate-pulse pattern of the IGBTs $g 1, g 2$, and $g 3$, during both positive and negative half-cycles, are shown in Fig. 9. This figure also shows the grid-side voltage and current, as well as the voltage $v_{a b}$. As expected due to the proposed control strategy, the IGBTs $g 2$ and $g 3$ are only switched during the negative and positive half-cycles, respectively. The IGBT $g 1$ is switched in both half-cycles, but only when voltage $v_{a b}$ varies between 0 and $+v_{d c} / 2$. This figure also shows a detail of the grid-side current and the IGBTs switching patterns.

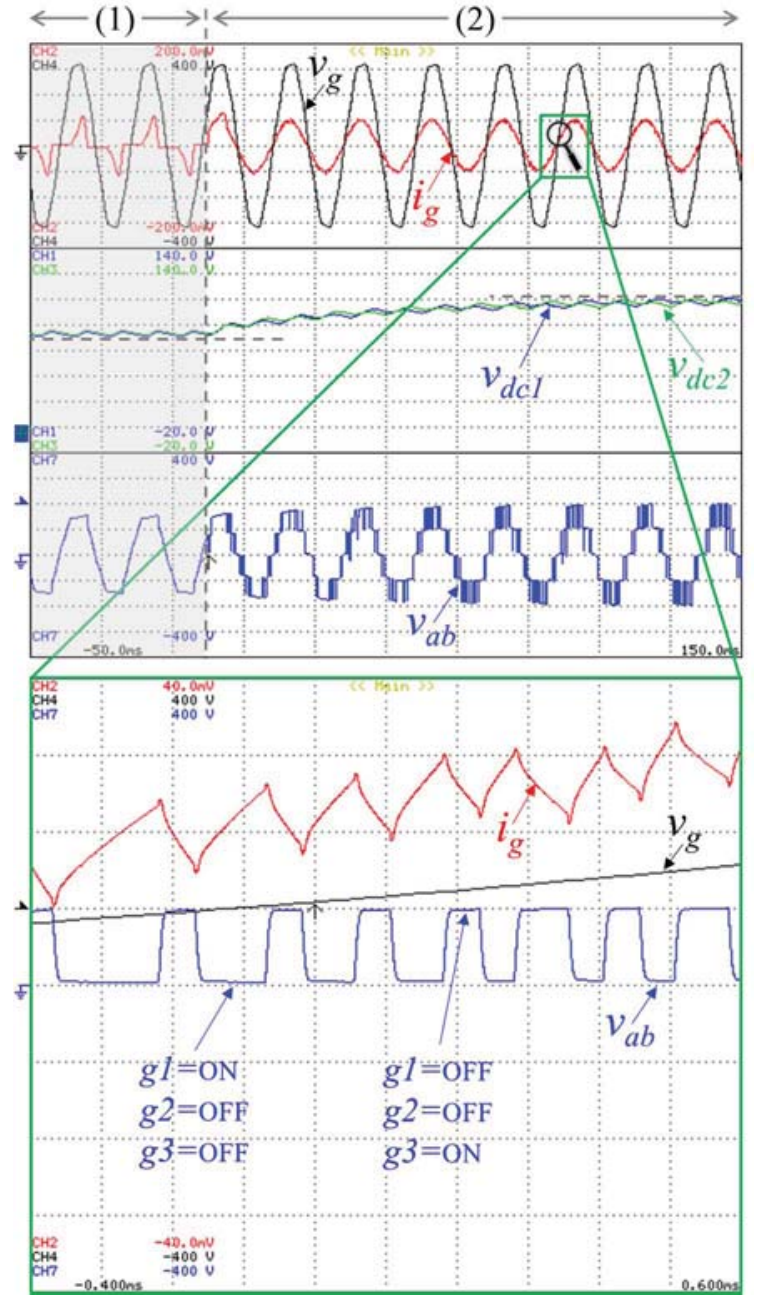

Fig. 8. Experimental results during the starting of operation: Grid-side voltage $\left(v_{g}\right)$; Grid-side current $\left(i_{g}\right)$; Dc-link voltages $\left(v_{d c l}, v_{d c 2}\right)$; Produced voltage $\left(v_{a b}\right)$.

\section{CONCLUSION}

This paper proposes a novel single-phase five-level VIENNA-type rectifier with model predictive current control. The principle of operation and the model predictive control are described in detail to demonstrate the feasibility of the proposed active rectifier and to support the obtained results. As demonstrated through simulation and experimental results, the proposed active rectifier operates with five voltage levels, allowing to obtain grid-side sinusoidal current and unitary power factor, with controlled dc-link voltage for all values of operating power, even during step-change variations of the power grid voltage or sudden variations of the load.

\section{ACKNOWLEDGMENT}

This work has been supported by COMPETE: POCI-010145-FEDER-007043 and FCT - Fundação para a Ciência e Tecnologia within the Project Scope: UID/CEC/00319/2013. This work is financed by the ERDF - European Regional Development Fund through the Operational Programme for Competitiveness and Internationalisation - COMPETE 2020 Programme, and by National Funds through the Portuguese funding agency, FCT - Fundação para a Ciência e a 


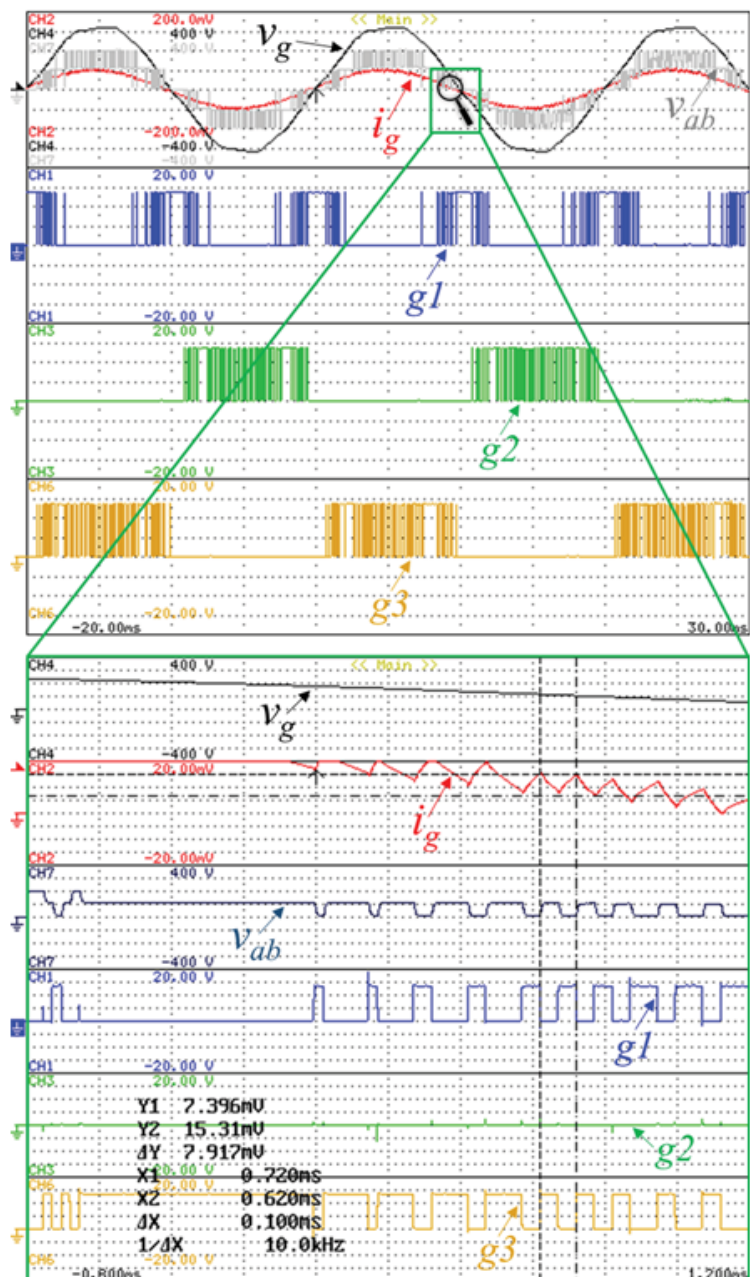

Fig. 9. Experimental results: Grid-side voltage $\left(v_{g}\right)$; Grid-side current $\left(i_{g}\right)$; Produced voltage $\left(v_{a b}\right)$; Gate-pulse patterns $(g 1, g 2, g 3)$.

Tecnologia, within project SAICTPAC/0004/2015 - POCI 01-0145-FEDER-016434.

\section{REFERENCES}

[1] Oscar García, José A. Cobos, Roberto Pietro, Pedro Alou, Javier Uceda, "Single Phase Power Factor Correction: A Survey," IEEE Trans. Power Electron., vol.18, no.3, pp.749-755, May 2003.

[2] Vítor Monteiro, Andrés A. Nogueiras Meléndez, João C. Ferreira, Carlos Couto, João L. Afonso, "Experimental Validation of a Proposed SinglePhase Five-Level Active Rectifier Operating with Model Predictive Current Control,“ IEEE IECON Industrial Electronics Conference, pp.3939-3944, Nov. 2015.

[3] Bhim Singh, Brij N. Singh, Ambrish Chandra, Kamal Al-Haddad, Ashish Pandey, Dwarka P. Kothari, "A Review of Single-Phase Improved Power Quality AC-DC Converters," IEEE Trans. Ind. Electron., vol.50, no.5, pp.962-981, Oct. 2003.

[4] Vítor Monteiro, Andrés A. Nogueiras Meléndez, Carlos Couto, João L. Afonso, "Model Predictive Current Control of a Proposed Single-Switch Three-Level Active Rectifier Applied to EV Battery Chargers," IEEE IECON Industrial Electronics Conference, Florence Italy, pp.1365-1370, Oct. 2016

[5] Bhim Singh, Brij N. Singh, Ambrish Chandra, Kamal Al-Haddad, Ashish Pandey, Dwarka P. Kothari, "A Review of Three-Phase Improved Power Quality AC-DC Converters," IEEE Trans. Ind Electron., vol.51, no.3, pp.641-660, June 2004.

[6] Johann W. Kolar, Thomas Friedli, "The Essence of Three-Phase PFC
Rectifier Systems—Part I," IEEE Trans. Power Electron., vol.28, no.1, pp.176-198, Jan. 2013.

[7] Thomas Friedli, Michael Hartmann, Johann W. Kolar, , "The Essence of Three-Phase PFC Rectifier Systems-Part II," IEEE Trans. Power Electron., vol.29, no.2, pp.543-560, Feb. 2014.

[8] João Paulo M. Figueiredo, Fernando L. Tofoli, Bruno Leonardo A. Silva, "A Review of Single-Phase PFC Topologies Based on The Boost Converter," IEEE INDUSCON International Conference on Industry Applications, pp.1-6, Nov. 2010

[9] Akira Nabae, Isao Takahashi, Hirofumi Akagi, "A New Neutral-PointClamped PWM Inverter,” IEEE Trans. Ind. Appli., vol.IA-17, no.5, pp.518-523, Sept. 1981.

[10] Johann W. Kolar, Franz C. Zach,“A Novel Three-Phase Utility Interface Minimizing Line Current Harmonics of High-Power Telecommunications Rectifier Modules," IEEE Trans. Ind. Electron., vol.44, no.4, pp.456-467, Aug. 1997

[11] Johann W. Kolar, Hans Ertl, Franz C. Zach, "Design and Experimental Investigation of a Three-Phase High Power Density High Efficiency Unity Power Factor PWM (VIENNA) Rectifier Employing a Novel Integrated Power Semiconductor Module," IEEE APEC Applied Power Electronics Conference and Exposition, vol.2, pp.514-523, Mar. 1996

[12] Johann W. Kolar, Uwe Drofenik, Franz C. Zach, "VIENNA Rectifier II-A Novel Single-Stage High-Frequency Isolated Three-Phase PWM Rectifier System,” IEEE Trans. Ind. Electron., vol.46, no.4, pp.674-691, Aug. 1999.

[13] Bachir Kedjar, Hadi Y. Kanaan, Kamal Al-Haddad, "Vienna Rectifier With Power Quality Added Function," IEEE Trans. Ind. Electron., vol.61, no.8, pp.3847-3856, Aug. 2014.

[14] Ooi H. P. Gabriel, Ali I. Maswood, Lim Ziyou, M. Abhinava Chaitanya, "Input Current Shaping of Five-Level Multiple-Pole VIENNA Rectifier Topologies with Reduced Component and Better Performance," IEEE IECON Industrial Electronics Conference, pp.900-905, Nov. 2013.

[15] Dan Floricau, Vasile Pangratie, "New Unidirectional Five-Level VIENNA Rectifier for High-Current Applications," IEEE IECON Industrial Electronics Conference, pp.1080-1085, Nov. 2013.

[16] Hani Vahedi, Philippe-Alexandre Labbé, Kamal Al-Haddad, "SinglePhase Single-Switch Vienna Rectifier as Electric Vehicle PFC Battery Charger," IEEE VPPC Vehicle Power and Propulsion Conference, pp.16, Oct. 2015.

[17] Thi Thuy Linh Pham, Frédéric Richardeau, Guillaume Gateau, "RealTime Monitoring for a Five-Level Double-Boost Power Factor Controller Including Postfault Reconfiguration," IEEE Trans. Ind. Electron., vol.60, no.9, pp.4128-4135, Sept. 2013.

[18] Samir Kouro, Patricio Cortés, René Vargas, Ulrich Ammann, José Rodríguez, "Model Predictive Control - A Simple and Powerful Method to Control Power Converters," IEEE Trans. Ind. Electron., vol.56, no.6, pp.1826-1838, June 2009.

[19] Vítor Monteiro, João C. Ferreira, Andrés A. Nogueiras Meléndez, João L. Afonso, "Model Predictive Control Applied to an Improved FiveLevel Bidirectional Converter,” IEEE Trans. Ind. Electron., vol.63, no.9, pp.5879-5890, Sept. 2016

[20] P. Zavala, M. Rivera, S. Kouro, J. Rodriguez, B. Wu, V. Yaramasu, C. Baier, J. Munoz, J. Espinoza, P. Melin, "Predictive Control of a Current Source Rectifier with Imposed Sinusoidal Input Currents," IEEE IECON Industrial Electronics Society, Vienna Austria, pp. 5842-5847, Nov. 2013.

[21] Bin Yu, Liuchen Chang, "Improved Predictive Current Controlled PWM for Single-Phase Grid-Connected Voltage Source Inverters," IEEE PESC Power Electronics Specialists, pp.231-236, June 2005.

[22] M. Karimi-Ghartemani, M. R. Iravani, "A Nonlinear Adaptive Filter for Online Signal Analysis in Power Systems: Applications," IEEE Trans. Power Del., vol.17, no.2, pp.617-622, Apr. 2002.

[23] Venkata Yaramasu, Marco Rivera, Bin Wu, Jose Rodriguez, "Model Predictive Current Control of Two-Level Four-Leg Inverters-Part I: Concept, Algorithm, and Simulation Analysis," IEEE Trans. Power Electron., vol.28, no.7, pp.3459-3468, July 2013.

[24] IEEE Std 519-2014, "IEEE Recommended Practice and Requirements for Harmonic Control in Electric Power Systems,” Revision of IEEE Std 519-1992, pp.1-29, June 2014. 